\title{
CANADA'S CONSTITUTIONAL OPTIONS
}

\section{J.P. MEEKISON*}

Professor Meekison sets out to identify and evaluate the options available in Canada's present constitutional impasse. He begins his analysis with a detailed review of the lengthy history of Canada's constitutional problems and the efforts made at various times to solve them. He then turns to the proposals expressed in the federal government's 1991 discussion paper, examining five of the more crucial ones in detail. Professor Meekison concludes on a note of cautious optimism.
Le professeur Meekison propose de definir et d'évaluer les options qui s'offrent au Canada dans l'impasse constitutionnelle actuelle. Il commence son analyse par l'historique détaillé des problèmes constitutionnels canadiens et des tentatives qui ont été faites à diverses époques pour les résoudre. II aborde ensuite les propositions que le gouvernement fédéral a formulées dans son document de travail de 1991, et examine les cinq plus importantes en profondeur. Le professeur Meekison conclut sur une note d'optimisme prudent.

\section{TABLE OF CONTENTS}

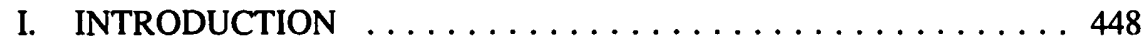

II. THE JOURNEY TO THE CROSSROADS $\ldots \ldots \ldots \ldots \ldots \ldots 450$

III. THE FIFTH PHASE: $1991-92 ? \ldots \ldots \ldots \ldots \ldots \ldots \ldots \ldots \ldots 457$

A. DISTINCT SOCIETY $\ldots \ldots \ldots \ldots \ldots \ldots \ldots \ldots \ldots 48$

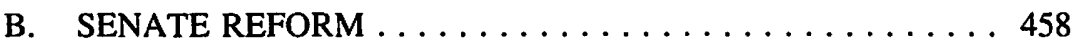

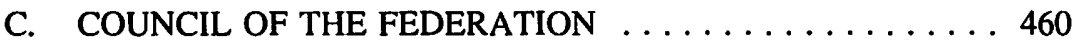

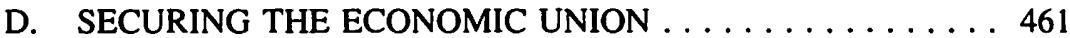

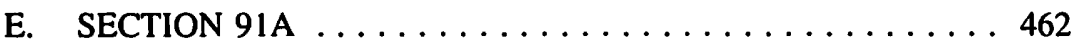

IV. SUMMARY AND CONCLUSION $\ldots \ldots \ldots \ldots \ldots \ldots \ldots \ldots$

\section{INTRODUCTION}

I have entitled this address Canada's Constitutional Options. At this stage we have only three choices. The first is maintenance of the status quo. The second is constitutional reform. The third is the breakup of the country.

Canada is at a constitutional crossroads. It is my basic assumption that the breakup of the country is not the preferred objective or solution of the vast majority of Canadians. Thus, while it is an option, and a very realistic one, it is not one that I intend to devote much time to. To me little is to be gained by trying to work out the design of a new Canadian constitution in the event that Quebec separates. Our time would be more profitably spent discussing how to improve our existing constitution.

What about the status quo? Is it defensible? Unfortunately it does not appear to be so. It should be remembered that at age 124 , our constitution is one of the oldest in the

Professor and holder of the Belzberg Chair in Constitutional Studies, University of Alberta. This paper is the text of Professor Meekison's Belzberg Lecture given at the University of Alberta on November 14, 1991. 
world. It has to date proven to be a highly resilient and remarkably flexible instrument. Under it Canada has developed a strong economy, an enviable standard of living, social programs such as medicare, official bilingualism, and an effective, although on occasion quarrelsome, federal system. Throughout our history we have been at peace internally. To be sure, we have had our problems, but to date we have been able to solve them within our existing constitutional framework. Until the 1982 constitutional amendment which added the Charter of Rights and Freedoms and the amending formula to the constitution, the basic text has not changed very much, although the constitution has changed a great deal.

Despite our past successes the status quo is no longer defensible. Change and improvement in our constitution are being demanded from a number of quarters. If it is not brought about it appears that a lengthy period of constitutional, and possibly economic, instability will result. The majority of Canadians are more concerned about the economy and the environment than they are about the constitution. And yet, on certain issues like language Canadians can become extremely passionate.

Recognition that the status quo is not a realistic alternative leads inevitably to the third option, constitutional change. The questions I would like to address are:

- how did we end up in this predicament,

- how should change be brought about, and

- what is up for discussion?

Before doing so I think it might be worthwhile to discuss briefly what is the nature and purpose of a constitution.

In his book Constitutionalism and the Separation of Powers, Vile wrote: ${ }^{1}$

The great theme of the advocates of constitutionalism... has been the frank acknowledgement of the role of government in society, linked with the determination to bring that govemment under control and to place limits on the exercise of its power.

A constitution outlines the machinery and structure of government - the role and selection of the executive, legislative and judicial branches, otherwise known as the separation of powers. If the constitution is federal, it outlines the division of powers and where the residual power rests. The constitution will need to provide ways of breaking deadlocks or constitutional impasses and a system of checks and balances. A means for amending the constitution is necessary. Finally, provisions for limiting or controlling government powers are often included. These can take the form of a charter of rights but there may also be other specific prohibitions (e.g. a prohibition of governments taxing one another). The constitution is our rule book.

(London: Oxford University Press, 1967) at 1. 
There is no requirement that constitutions be of a standard length. There are no fixed constitutional recipes. Nor is it possible for them to provide in detail for every eventuality which the modern state must address. Essentially they are skeletal documents. Constitutions are changed over time as they are interpreted and adapted. They develop their own lustre or patina - worn, loved, but functional.

Conventions emerge which may be as significant as constitutional clauses themselves. Conventions are the so-called unwritten part of the constitution. The obvious example in Canada is our system of cabinet government. Nowhere in our constitution does it refer to a cabinet or prime minister. They have just come to be accepted as the way things are. I raise these points just to remind us that, no matter how precise constitutional architects are in their language, constitutional change and adaptation is inevitable. The courts will be asked to make rulings that result in changed interpretations. New procedures will evolve through convention. By contrast, formal amendments could be termed the minor or major corrections in the course of the ship of state.

\section{THE JOURNEY TO THE CROSSROADS}

Where does Canada's constitutional odyssey begin? The journey did not begin in 1990 with the demise of the Meech Lake Accord. When, then, did it start? For me, the logical beginning of the debate is with the establishment of the Royal Commission on Bilingualism and Biculturalism (the B \& B Commission) in 1963.

In their Preliminary Report published in 1965 the Commissioners stated: ${ }^{2}$

The Commissioners...fully expected to find themselves confronted by tensions and conflicts. They knew that there have been strains throughout the history of Confederation.... What the Commissioners have discovered little by little, however, is very different: they have been driven to the conclusion that Canada, without being fully conscious of the fact, is passing through the greatest crisis in its history.

This conclusion was stated in $1965-26$ years ago. A joint parliamentary committee in 1972 produced a far-reaching and comprehensive report on the Constitution of Canada. They declared that Canada "is in the midst of the most serious crisis in its history."

The Pepin-Robarts Commission established by the federal government in 1977 released its report entitled $A$ Future Together in January 1979. They too emphasized that Canada was in the midst of a crisis. They also issued a warning.

2. Canada, A Preliminary Report to the Royal Commission on Bilingualism and Biculturalism (Ottawa: Queen's Printer, 1965) at 13.

Canada, Special Joint Committee of the Senate and House of Commons on the Constitution of Canada, Final Report (16 March 1972) at 3. 
We recognize that even crises can become tedious and difficult to believe in if they go on too long and if nothing seems to happen. ${ }^{4}$

In June 1991 the Spicer Commission released its report. One observation stands out.

This pan is the commissioners' voice. And we must tell you clearly: Canada is in a crisis. This is a crisis identified and experienced by the people of Canada as immediately as a drought affects a farmer. This is a crisis of identity, a crisis of understanding, a crisis of leadership. We have arrived at this conclusion not because participants used the word crisis - few of them did - but because what they told us adds up, mercilessly, to this conclusion. ${ }^{5}$

Thus one can trace the theme of continuing constitutional crisis back over the last quarter century. This sense of crisis or impending doom, detected by four very diverse groups, all of which criss-crossed Canada, has tended to affect how Canadians now approach constitutional reform. Skeptics will argue that we have heard this message for so long and so often we simply do not believe it any more. There are others who say the crisis has now reached the point where the volcano is about to erupt. There are others who have simply given up on ever resolving the matter, a condition I call the constitutional fatigue syndrome. Our inability or unwillingness to settle the issue has brought us to this point.

If one retraces the path from the B \& B Commission through to the recent federal government position paper released in September, one can find four distinct periods of constitutional discussion and negotiation. With the release of the federal paper we have now entered the fifth and in my opinion final phase.

Phase I: 1968-1971. In this period the basic outline of the constitutional agenda for the next twenty-five years was developed. Some matters such as the Charter of Rights, language, patriation, the amending formula, and constitutional recognition of the principle of equalization were identified and resolved in 1982. Others such as Senate reform, the Supreme Court and its composition, the division of powers, the federal spending power, and a provincial role in international affairs remain to be finalized. This phase ended when agreement was reached in June 1971 - the Victoria Charter. Hopes were dashed when Quebec, a few days later, withdrew its support.

Phase II: 1974-1979. This phase begins in September 1974 immediately after the federal election. Prime Minister Trudeau informed Canadians that it was his intention to patriate the constitution from the United Kingdom, and secure a constitutional amending formula during the life of the new Parliament. In 1976 the Parti Québecois was elected Canada, 1979) at 11.

5. Canada, Citizens' Forum on Canada's Future, Report to the People and Government of Canada (Ottawa: Supply and Services Canada, 1991) at 113. 
and Canadians came face to face with a government dedicated to the fundamental restructuring of the country and federal system.

Unlike the previous phase, this five-year period did not have a highly structured series of constitutional conferences and meetings. Instead it was characterized by informal discussions, exchange of correspondence, interprovincial meetings, and two First Ministers' Conferences held in late 1978 and early 1979. There was no agreement or resolution. No document comparable to the Victoria Charter was produced.

During this phase the subject of natural resources became increasingly important and was placed on the agenda. While by no means dominating the agenda, its inclusion made a significant difference to the debate. If language was seen as a matter of interest to Quebec and equalization to Atlantic Canada, natural resources were seen as a priority for the western provinces.

In 1979 aboriginal priorities were raised and the federal government signalled its intention to discuss its own constitutional priority, the economic union, at future conferences.

Phase III: 1980-1982. After the defeat of the Quebec referendum in May 1980 there was a collective sigh of relief across the nation. The country had been brought to the brink of emotional and constitutional exhaustion. Now the way was clear for a series of intergovernmental meetings which led to the Constitution Act, 1982. The federal government, the western premiers, other provinces, Canadians across and throughout the country pledged to resolve Quebec's constitutional grievances once and for all if Quebecers would vote "no" in the referendum. They did.

One last effort to secure a federal-provincial agreement took place in the summer of 1980. The subject of the economic union was added to the list of matters to be considered; otherwise the agenda was virtually the same as before. The summer's negotiations produced a series of reports from a number of subcommittees consisting of ministers and officials and an apparent degree of success. However, this seeming unity dissolved at the FMC in September. The long and the short of it was that the conference ended in deadlock. The federal government eventually decided to proceed with patriation of the constitution unilaterally. It did so and the provinces divided 8-2 in opposition.

To garner support for the federal package a parliamentary committee was established to hold hearings on it. In retrospect, this change in the process represented a watershed in Canadian constitutional development. Up to this point, different parliamentary committees and commissions had heard commentary from the public about general issues. They had not, however, asked people to react to a specific text, let alone make changes to that text. The 1980-81 parliamentary committee was therefore fundamentally different in its approach and mandate. Its role was pivotal in galvanizing public opinion around the Charter, the centrepiece of the proposal. 
The opposing provinces, known as the Gang of Eight, challenged the federal government's unilateral action and won before the Supreme Court of Canada. This resulted in one last attempt to resolve matters through negotiation and compromise. A conference was held in early November 1981, just ten years ago last week. After a few days of intense discussion the Constitution Act, 1982 took shape and all provinces except Quebec gave their consent.

Quebec felt betrayed and humiliated. It did not participate in the all-night discussions which led to the consensus. It is one of the great ironies of our history that, after so many years and discussions with a view to resolving Quebec's constitutional problems, the final agreement excluded Quebec. As long as Quebec remains apart, constitutional reform will remain unfinished business.

Phase IV: 1987-1990. Bringing Quebec back into the constitutional framework of Canada was imperative. That objective was achieved at the meeting which drafted the Meech Lake agreement in 1987.

Meech Lake was the end or culmination of the first major series of changes to the Canadian Constitution since 1867. It incorporated the minimum demands necessary for the Province of Quebec to accept politically, and thereby legitimize, the constitutional reforms which were proclaimed in April 1982. It cannot be forgotten that Quebec had not signed and vigorously disagreed with the agreement reached in 1981 which led to a reference case on whether or not Quebec had a veto over constitutional change. It did not.

The Meech Lake agreement must be seen as the end result of a long series of negotiations going back to 1968. It was not an isolated event in our history. Prior to 1968 the objective of constitutional reform was limited to patriation and securing agreement on an amending formula. This dominated constitutional discussions from 1927 to 1964. Quebec's Quiet Revolution changed this narrow focus. Premier Lesage, when he rejected the Fulton-Favreau amending formula in 1965, did so believing that it would prove a millstone to Quebec's more extensive constitutional aspirations. So for the past twenty-six years Quebec's concerns have been central or pivotal to the reform process. They are still so today.

By Quebec's concerns being central to the process I do not mean that other items have not been added to the agenda. They have, increasingly, and today the agenda is crowded, possibly overcrowded. For most of the time, other provincial governments either did not take constitutional reform seriously or were prepared to discuss Quebec's concerns but only in the context of a more general review. Hence the agenda spread out like a vast river delta with the main channel often being hard to find. Indeed the 1971 Victoria conference was convened at a time when English-speaking premiers were becoming concerned with the time and energy constitutional discussions took away from other, seemingly more important, issues. They wanted to get it over with and talk about the economy. This sentiment was perhaps best captured by Ross Thatcher's immortal words. 
He said if Saskatchewan had a hundred concerns, constitutional reform was the hundred and first.

The late seventies saw a marked change in the ambivalence towards constitutional reform of many of the other provinces. There was the emergence of the new West and its concern over natural resources. The West believed it lacked influence at the centre. Western involvement and advocacy in the reform process increased as a result. From this interest came the principle of provincial equality and a demand for institutional reform, especially Senate reform. The developing position also led to decentralizing tendencies or pressures which were not acceptable to the federal government - a fact clearly underscored in a 1980 speech by Mr. Trudeau where he referred to the growing regionalism in Canada as "the enemy within," a concept he took from the cartoon strip Pogo.

At the same time, aboriginal people were pressing for constitutional recognition. As a direct result of the Constitution Act, 1982, a series of four constitutional conferences were held between 1983 and 1987 and were devoted entirely to aboriginal questions. While these were First Ministers' Conferences, participation was expanded to include representatives from both territories and four aboriginal organizations. The last conference, in the spring of 1987, which focused primarily on aboriginal self-government, ended in failure. When Meech Lake was agreed to a few weeks later, aboriginals questioned why there could be accommodation for Quebec and not for them. Why could Quebec be recognized as distinct and not the native peoples? Aboriginals saw this as a double standard, and in June 1990 Elijah Harper, the Manitoba MLA, was successful in blocking the Meech Lake agreement in the Manitoba Legislature.

Thus far I have addressed how we journeyed to the crossroads. The next question to be considered is, how should change be brought about?

Up to 1982 all discussions or negotiations took place in the absence of an amending formula or any agreed-upon mechanism for change of the constitution. Agreements reached were primarily a product of intergovernmental negotiations, a process known as executive federalism. With an amending formula in place the dynamics of change were fundamentally altered. After the negotiations had been concluded a second process was necessary, ratification. With formal ratification there came a demand for public involvement. The old processes were no longer acceptable. Public participation and consultation, which started in 1980-81, is now seen to be an essential part of the process. The amending formula also established a three-year time limit on securing amendments.

Also of importance is that the Canada of today is not the Canada of 1968 when the process started. While the agenda and the reasons for constitutional change were clear in 1968, the dynamics of change today are very different, complicating the process even more. Individuals and groups are now far more interested in the process and the agenda than they were in 1968. 
What are the stages of constitutional reform? They shift from agenda setting to negotiation to ratification. As already mentioned, up to Meech Lake, Canada amended her constitution primarily through the processes of executive federalism. This is certainly how many amendments had been shaped in the past and, up to 1982, how amendments were ratified. Before 1980 there had been a parallel (but ad hoc) process of public consultation primarily through Royal Commissions such as the 1937 Rowell-Sirois and the 1963 B \& B Commissions. The Pepin-Robarts task force and the 1970-72 parliamentary committee gave people an opportunity to express their opinions. The purpose of the different committees, commissions and task forces was to elicit views on broad questions about the functioning of the country and the federal system. It was up to the commissioners or parliamentarians to distil what they heard and present their findings, conclusions and recommendations.

Over time, a number of conventions developed around the conduct of First Ministers' Conferences. Many of the conferences were televised; although it did not involve the public directly, television certainly informed them about the issues and the different positions taken. People could see part of the negotiations.

The 1980-81 parliamentary hearings on the patriation package were a turning point. Individuals and groups were asked for their views on a specific proposal and their comments helped to shape the final outcome. In retrospect, after that there could be no turning back. It must be remembered that most of what was being discussed had been through the sieve of federal-provincial negotiations and large parts of it had been endorsed by governments at one time or another.

If I were asked to say which had the greater impact on the failure of Meech Lake, process or content, I would say process. After having been invited into the process in 1981, Canadians were told in 1987 they would have absolutely no influence or say in the outcome. Why was this done? Because it was felt by the eleven governments that once negotiations had been concluded and the necessary compromises reached, it would be exceedingly difficult to reopen them. This is often referred to as the seamless web argument.

There are really two different but interrelated questions here. The first is, should the public become directly involved in the negotiations? The second is, should the public be directly involved in the ratification process where the only result possible is yea or nay as opposed to leaving the decision to legislatures. By using the seamless web argument people could say to governments, fine, we realize we can't make changes but let us at least have an opportunity to debate the proposal and then decide to accept or reject it.

What is the best path for us to follow in light of the Meech Lake experience? From my perspective public involvement is most crucial in the preliminary stages - shaping the agenda and influencing the negotiations and, hence, the final document. The amending formula provides for an open ratification process. If there has been full and adequate discussion leading up to the final draft of the amendment, I believe the matter can be left 
to elected legislatures to make the decision. If as a result of the debate in the legislatures fresh problems emerge, there is nothing to prevent further negotiations to clarify issues. My expectation is that the more the public are involved at the beginning the more likely they will respond positively to the final result.

What must be recognized is that at some point some group - and in my view that group is governments - must conduct negotiations on amendments. The problem with Meech Lake was that once this was done the governments said no changes were possible. In retrospect this attitude sealed the fate of the agreement. Some form of public participation after negotiations have started but before they have concluded is now essential.

There is clearly an interest in having a referendum on constitutional recommendations, i.e. a say in the ratification of the final agreement. This is evidenced by results on referendum questions held during the recent B.C. and Saskatchewan elections. Premier Getty has hinted Alberta may hold a referendum, and the Manitoba Committee on the Constitution recently suggested the idea be considered in that province. ${ }^{6}$ There is strong pressure from organizations such as the Canada West Foundation to hold them at the provincial level. But are referenda the best way to go? Referenda are not legally binding on any government or legislature and can range from asking people their preferences on a matter, to approval of a proposal similar to the Meech Lake Agreement. If the results of the vote are in favour of the proposal, no problem. If they are opposed, government is left with the alternative of reopening negotiations or opposing the matter in the legislature. Should such consultation take place prior to negotiations? Questions such as do you favour provincial equality or do you favour a Triple E Senate could be asked. The response could serve as a guide to negotiations. Do such polls serve to strengthen or weaken a province's position? The answer of course depends on the outcome and the degree of support for a question.

While a referendum is the ultimate expression of the popular will, the choice that is left to the voter with respect to ratification is only yes or no. Problems associated with a referendum include the questions of who defines the question, who speaks for or against, who pays for the referendum costs, what is the role of government, and when is the referendum held?

It is possible that pressure will build for a national referendum. At least, in this instance, one knows that the vote will be held on the same day across the country and that it will likely be government-sponsored and financed. How long should the campaign period be? More important, what constitutes a win? The referendum would have to carry in at least the same combination of provinces as required under the amending formula, i.e. two-thirds representing fifty percent of the population. What happens if it passes in

6. Manitoba, Report of the Manitoba Constitutional Task Force (28 October 1991) (Chair: W.N. FoxDecent) at 61 . 
the rest of the country and not Quebec? Does the federal government, whose parliamentary majority rests on a Quebec base, proceed? These hypothetical questions need to be addressed beforehand. Once the vote is called it will be too late. We have had no tradition of such processes, and while the idea may have its appeal, I am not sure it is the most prudent course of action to be followed. Referenda can be very divisive.

\section{THE FIFTH PHASE: 1991-92?}

Let me turn now to the federal government position paper called Shaping Canada's Future Together. ${ }^{7}$ It is obvious from reading it that the government has learned a number of lessons from the Meech Lake experience. The public is encouraged, indeed urged to become involved in the debate - "Every Canadian will have the right - and the responsibility - to participate." ${ }^{18}$ Individuals can phone a toll-free number to make their views known, a technique first used by the Spicer Commission. A parliamentary committee was established and until its demise was travelling across the country meeting with provincial committees and holding public hearings.

A substitute process has now been cobbled together. Whether it will be successful remains to be seen. In some way the public must be involved at this agenda-setting stage. The proposed meetings will accomplish that to some extent, but they are a less than satisfactory substitute for public input from across Canada. On the other hand we may be witnessing the emergence of a quasi-constituent assembly.

It must be remembered that the parliamentary committee was to write a report which the government would take into consideration in preparing its final position. The government still needs to produce that report and there needs to be public input before it does. Once that report is complete the government will need to discuss it not only with the provinces but also obtain public reaction. My concern is that we appear to be developing new and as yet undefined processes at the eleventh hour.

What does the federal proposal contain? It has 28 separate recommendations, and among other things touches on institutional concerns, aboriginal issues, the economic union, the division of powers, and the distinct society of Quebec. In some instances draft constitutional language has been provided; in others only an idea has been presented. With the new process that appears to be unfolding we may be very close to backing into negotiations before several of the provincial committees have completed their deliberations. The process appears to be completely open-ended with respect to its content and is limited only by time constraints. There is certainly no "take it or else" approach this time around. Questions I have heard asked are whether there is now too much on the table and whether the public will be able to digest the entire package. It

7. (Ottawa: Supply and Services Canada, 1991).

8. Ibid. at 50. 
should also be noted that none of the recommendations requires unanimity, another lesson learned.

Some see the document as centralizing, others as decentralizing. The reality is that both tendencies can be found. There are elements of the Meech Lake agreement in the proposal, recognition of the 1991 Allaire report of the Quebec Liberal Party, recognition of western demands for Senate reform, and recognition of a federal concern for strengthening the economic union. The document is a hybrid mixture of constitutional proposals and ideas. There is little that is new in the federal proposal although there has been some repackaging. Thus to a certain extent many of the issues have been discussed before, while a few have not.

Time does not permit a detailed analysis of the proposal. I would like to comment briefly on the recommendations on the distinct society clause, Senate reform, the Council of the Federation, the economic union, and the proposed new federal legislative authority on the economy.

\section{A. DISTINCT SOCIETY}

One recommendation which has drawn considerable attention thus far is that on the distinct society clause. This is not surprising because that part of the Meech Lake agreement was probably the most scrutinized and criticized provision of all. Instead of being a free-standing clause in the constitution it is now to be incorporated into the Charter of Rights as one of several interpretation clauses. Distinct society reflects the reality of the Canadian polity and the 1867 Confederation agreement. As part of the Charter, it is subject to all Charter interpretations and limitations such as the other interpretation clauses. The clause is not given primacy of place within the Charter and does not give Quebec special status. While often debated there also appears to be a growing recognition that this clause, or something equivalent to it, is necessary if an overall agreement with Quebec is to be reached. Recent supportive comments by both Premier Clyde Wells and the National Action Committee on the Status of Women suggest that this time the phrase has a better chance of being accepted. In my view, this clause, given its now symbolic importance in Quebec, is a deal-maker or breaker.

\section{B. SENATE REFORM}

The federal government's position on Senate reform suggests it is in favour of change but it has not fully embraced the Triple-E concept (equal, elected and effective). The parliamentary committee had considerable latitude in developing the final position; that responsibility will now rest elsewhere. One of the key references in the document is the following statement: "... the reality of contemporary Canadian politics is that provinces and territories, and not regions, are basic to our sense of community and identity." 
While the proposal clearly supports equitable representation, it does not completely rule out the idea of equal representation.

There can be little doubt that Senate reform appears far more probable today than it did a few years ago. The federal proposal suggests that Senate elections should coincide with elections to the House of Commons. I disagree because Senate election results would mirror those in the House of Commons. The justification for a second chamber in a federation is that provincial interests should be reflected there. Elections to the Senate could coincide with provincial elections as was proposed by the Alberta Select Committee on Senate Reform. Another alternative is fixed term elections with part of the membership being elected at set intervals, e.g. a six-year term with half the members selected every three years. Whatever model is chosen, I feel that every effort should be made to avoid a situation where the two houses are elected simultaneously.

How effective is the Senate to be? Is it to be a legislative chamber with authority comparable to the House of Commons? At first glance it would appear to have major responsibilities. Closer inspection suggests there may be some significant limitations to this authority.

The federal proposal identifies three degrees of legislative activity for the Senate:

1. areas where the Senate must give its approval, i.e. an absolute veto (which it has now),

2. areas of "national importance" such as national defence and international relations where there would be a six-month suspensive veto, and

3. money bills where the Senate would have no say at all.

There are a number of problems here which require further analysis. As long as we adhere to a parliamentary system of government, it stands to reason there can only be one confidence chamber, the House of Commons. But that should not preclude debate in the Senate on money bills. A suspensive veto of 30 days, a delay comparable to that of the House of Lords in the United Kingdom, is not an unreasonable limitation. What is more problematical is defining a money bill. For example the 1980 National Energy Program was introduced as part of the federal budget. Was it therefore a money bill and as a result a matter of confidence? Moreover even when a definition is agreed to, some kind of mechanism for dispute resolution will be required. To me, resort should be to a parliamentary committee of some kind, and not the courts.

An equally difficult challenge will be to define and secure agreement on what constitutes a matter of "national importance" and therefore is not subject to a Senate veto, but only a six-month delay. One assumes from the very beginning that most federal legislation is of national importance. Examples would be the Criminal Code, Supreme Court Act, Elections Act, Official Languages Act, National Transportation Act, Canada 
Health Act, and Fiscal Arrangements Act to mention but a few. The limitation on international issues would likely prevent the Senate from reviewing matters such as the Free Trade Act which was essential to implementing the Free Trade Agreement. While these questions need clarification, they are certainly capable of resolution. The net result will be a more effective second chamber.

What must be recognized is that any new chamber will have an enormous impact on the legislative process and hence public policy. It will take several years before working relationships between the two houses become fully established. Giving greater weight to western and Atlantic regions will create a much stronger regional influence in decisionmaking at the centre.

If equal representation becomes a reality, influence from outer Canada will be that much greater. The most contentious issue of Senate reform is the question of provincial equality. The federal paper has pushed for more "equitable" treatment of provinces, which suggests there will be some redistribution of seats but not necessarily equal treatment of the provinces. As one can see from the foregoing, there is much to debate and discuss on this recommendation, and I have not even mentioned the proposed power to approve certain appointments!

\section{COUNCIL OF THE FEDERATION}

Another major institutional change under consideration is establishment of a new decision-making body called the Council of the Federation. The proposal under discussion today is tantamount to entrenching a system of executive federalism in the constitution, an approach I certainly support.

The reality of Canadian federalism is that succeeding federal and provincial governments have worked together to solve many of our country's problems. While we may tend to think in terms of "watertight compartments" in the constitution, the reality of modern government is a growing interdependence. As reported by the Spicer Commission and reflected in the federal proposal, the public favours elimination of program duplication and disentanglement of overlapping jurisdiction. But this is not always possible. In some areas such as fiscal policy, environment, or economic development, intergovernmental discussion and co-operation are essential to produce harmonious policies. The fact of the matter is that despite our differences and conflicts we keep returning to the model of executive federalism because it has been an effective way of resolving intergovernmental disputes and a means of seeking common ground.

The question which inevitably arises is, can our constitution and political system sustain both Senate reform and a Council of the Federation? In my view the answer is yes because they do not overlap with respect to their responsibilities. A reformed Senate as outlined in no way diminishes provincial legislative responsibilities under the constitution. It makes the government of Canada more sensitive to provincial and regional interests in developing its legislative program, but always within its constitutional sphere. I agree that 
there is always the potential for a clash between the representatives of the provinces in the Senate and provincial governments. But the responsibilities of the Council are clearly linked with spheres of provincial legislative authority and do not depend upon actions taken by the Senate. The possibility of competing interests will need to be taken into consideration when both institutions are examined.

\section{SECURING THE ECONOMIC UNION}

Of the various provisions contained in the federal proposal I suspect those relating to the economic union are among the most important to the federal government. First of all, what is an economic union? Essentially it is seeing Canada as a common market where there should be the free and unimpaired movement of goods, services, capital, and people throughout the country. But Canada is a federal system, and both the federal and provincial governments have responsibilities to manage their respective economies. Over time provinces have established a variety of policies and practices which impede free market forces. While Parliament's authority over trade and commerce is extensive, it is not sufficient to curb many of these practices.

While there is a common market clause in the constitution $-\mathrm{s} .121-$ it has not served as the kind of constitutional restraint to provincial activity one might expect. As a result of its rather limited scope the federal government has recommended an expansion of this clause to prohibit any barrier to the free movement of goods, services, capital, and persons. This sweeping constitutional provision would apply to both the federal and provincial governments. There are to be exceptions, however, for federal laws "enacted to further the principles of equalization or regional development." Provinces also get a measure of relief with respect to their efforts to eliminate regional disparities within the province provided there is no extra-provincial advantage established. Finally, there can be other federal or provincial exceptions if sanctioned by the Council of the Federation.

This new clause will have enormous implications for a wide range of provincial government policies including agricultural supply marketing boards, procurement, product standards, and licensing of professions to mention some examples. While few would find fault with the principle behind the desirability of such a clause, i.e. economic integration, the question arises whether there are non-constitutional alternatives such as uniform legislation or commitments to reduce such barriers. The answer is yes, and they need to be weighed against such a sweeping clause in the constitution. While the exceptions are understandable they lay the foundation for a great deal of controversy and future litigation. For example, I don't see how federal procurement policies could be challenged as long as they were linked to regional development.

I am sceptical about the chances of this clause being approved in the time available. It is so all-encompassing that I would be surprised if most provinces did not demand an opportunity to discuss it in greater detail if for no other reason than to seek clarification. Whether or not there should be other exemptions was left to the now defunct 
parliamentary committee to explore. While it is clear that barriers to trade should be eliminated or curtailed, it must be remembered that many provincial policies are often developed for social reasons and not for purposes of economic efficiency. To me this is a highly centralizing feature of the federal constitutional package. In my view the effect on the provinces is far greater than on the federal government and accordingly one can expect them to question the clause.

\section{E. SECTION 91A}

The companion provision to the new common-market clause is one which would give Parliament an exclusive authority to "make laws in relation to any matter that it declares to be for the efficient functioning of the economic union." Before Parliament could exercise its authority it would first need the approval of two-thirds of the provinces representing fifty percent of the population. The forum for securing approval is the Council of the Federation. It must be appreciated that the threshold of support is identical to that found in the amending formula. Consequently one might conclude that the new federal authority will be used infrequently and when it is, the same objective could be achieved through the amending formula - so why worry?

There is a worry, however, and a word of caution. To insert this amendment into the constitution will require two-thirds of the provinces representing fifty percent of the population. That means at least seven provinces must agree to it, and one must assume those seven have fully considered its implications. But what about the other three? Unless they specifically register their dissent under the provisions of the 1982 amending formula they will be subject to $\mathrm{s}$. 91A. In other words, if a province wishes to object to this new federal legislative power the time to register its dissent is before the proposed amendment is proclaimed. Dissenting provinces then have available to them the optingout provisions of the amending formula found in s. 38(3). There is no way whatsoever that Quebec will accept this clause as it is now drafted. This fact means that Ontario will have the final say on its insertion into the constitution since without it the fifty percent threshold is not fulfilled.

The draft which is being considered provides for a province to opt out once for a threeyear period. After that the objecting province would be subject to the federal authority whether it liked it or not unless it had previously exercised its right to declare the amendment non-applicable. Those who accepted the amendment will have waived that right by accepting it.

If the federal government expects the clause to be accepted it will need to make at least two modifications to the proposal. First, allow for provinces to opt out for a fixed period and agree that opting out can be renewed an indefinite number of times. Second, require the federal legislative authority to be renewed periodically, say every five years. Why? One reason is that it will allow those provinces which have agreed to a transfer to change their minds - particularly after a change in government. It will also allow for fine-tuning of the federal legislative authority. It also means that there is clear recognition that the 
provincial legislative authority is only temporarily borrowed. There are some strong parallels here to fiscal arrangements which have been the subject of five-year reviews over the past fifty years. Unless changes along the lines I have suggested are added, Section 91A has no chance of being adopted. Few, if any, provinces will be prepared to write a blank cheque.

Assuming good intentions on the part of the federal government, I am gradually coming to the conclusion there is simply too much on the table at this time. Moreover the agenda is expanding, with matters such as a social charter being added by Ontario and equalization and Established Programs Financing being added by Manitoba. There has been no mention of removing the federal government's powers over disallowance and reservation or of providing a provincial role in international affairs, all of which have been discussed before. It is difficult to see when agenda-building will end. Everything cannot be discussed at once and everything cannot, and should not, be in the constitution. We are better off leaving things out and leaving them to the political process than inserting them into the constitution. The constitution can not solve all our problems.

\section{SUMMARY AND CONCLUSION}

Let me try to summarize briefly. We have retravelled the route to our crossroads, journeying from 1968 to 1991. Along the way we have seen the wreckage of earlier constitutional discussions such as the Victoria Charter and the Meech Lake Accord. We have seen the same agenda items appear on the horizon every few miles with new ones occasionally dotting the landscape. And now we must make a choice as to which path to take. Some will look for detours - there really aren't any available this time.

Making choices is difficult, but we must ask ourselves: are we prepared to take the federal package plus proposals as yet unknown from the variety of provincial committees and make a decision about our constitutional future? Do we have time to make the difficult decisions which of necessity must involve compromises? We are in a real race because one of the contestants has stated it has another race to run within a few months. That complicates the logistics of our race because if one of the contestants leaves before we have finished a new set of rules of the road must be developed.

What do the signposts say? Unfortunately because of the terrain we cannot see over the hills or around the next corner to give us any hints as to what lies ahead. One sign says "danger, bridge washed out, insurance cancelled if road used, journey at own risk." The other says "opportunity, watch for rocks on road, icy patches ahead, proceed carefully." To me the first choice of break-up is not a viable alternative. It is equivalent to driving downhill without any brakes and no runaway lanes - not a pleasant thought. The other appears to offer the most promising route.

It will be tempting to try to put all of our constitutional luggage in the car as we start out. Some may get left behind while other pieces are lost or discarded along the way. Still other pieces may be acquired en route. There will be eleven cars on the road and 
we must decide early in our journey whether or not we can make it by ourselves or travel in convoy to assist one another. There is also a provision for late entrants who may require adjustments to the rules.

Somewhere along the way, once the general direction has been agreed upon, the drivers will need to meet to make final decisions about loads, provisions, way stations, and other refinements to make the race a success. It will be necessary for each driver to consult with the passengers, but at some point drivers must resolve the details of the journey. For some participants that will be difficult because they have been in the back seat, others will have concentrated on the rear-view mirror, still others will not have kept track of the surroundings and may feel lost, and others will not have learned to drive. There is always a chance of a mishap with too many hands on the wheel and with nobody looking out for possible obstructions or icy patches.

Just before the participants cross the finish line it will be necessary to ask the passengers to give an indication whether or not in their opinion the race was worth the effort. Along the way there will be supporters who can watch and offer words of encouragement. Others may try to suggest detours or long rest stops. We do not have time to be distracted lest the race not be completed. To me it is a journey whose challenges are worth the effort because the prize across the finish line is a united Canada. 